\title{
The Impact of Building Coverage in the Metropolitan Area on the Flow Calculation
}

\section{Chen-Jia Huang ${ }^{1}$, Ming-Hsi Hsu ${ }^{1,2, *}$, Wei-Hsien Teng ${ }^{3}$ and Yen-Hsiang Wang ${ }^{1}$}

1 Department of Bioenvironmental Systems Engineering, National Taiwan University, No.1, Section 4, Roosevelt Road, Taipei 10617, Taiwan; E-Mails: d94622003@ntu.edu.tw (C.-J.H.); kevinwang963@hotmail.com (Y.-H.W.)

2 Department of Civil and Disaster Prevention Engineering, National United University, 1, Lienda, Miaoli 36003, Taiwan

3 Department of Architecture, National United University, 1, Lienda, Miaoli 36003, Taiwan; E-Mail: wsteng@nuu.edu.tw

* Author to whom correspondence should be addressed; E-Mail: mhhsu@ntu.edu.tw; Tel.: +886-2-33663468; Fax: +886-2-23631209.

Received: 22 April 2014; in revised form: 5 August 2014 / Accepted: 8 August 2014 / Published: 14 August 2014

\begin{abstract}
Due to the special hydrographic and physiographic conditions in Taiwan, flooding is likely to occur in the middle and lower reaches of a plain whenever serious rainstorm events occurred. Note worthily, the loss of lives and property caused by flooding are always most considerable in a metropolitan area, and the densely distributed buildings would, not only increase the impervious area, but also decrease the water storage area. Furthermore, a large number of intensive buildings have changed the original land flow conditions, resulting in a beam shrinking flow and the additional form drag phenomenon, which makes the flooding phenomenon more serious. The main purpose of this research is to find the correlation between building coverage and the Manning's coefficient $\mathrm{n}$ through a water flume model experiment. To probe into this issue, the Manning's roughness adjustment is further divided into a part caused by the surface impedance and a part caused by the building impedance. Thus, building coverage can be added to the general computing grid to reflect the flooding situation with buildings. The two-dimensional inundation model, based on this research, was applied to Taichung City for an actual case simulation. The simulation result of Typhoon Kalmaegi showed that the presented model can obtain a more accurate flooding situation in urban area by considering the blockage effects of buildings and adjusting the surface roughness.
\end{abstract}


Keywords: flume model experiment; Manning's roughness adjustments; two-dimensional inundation model

\section{Introduction}

Recently, higher, or more refined, resolution topographic data have been widely used in urban inundation modeling to represent the complicated flow patterns around buildings [1-3]. However, implementations of these detailed topographic data often require extraordinary computational timing, which is insufficient in real-time flood forecasting. To improve the efficiency of modeling, grid coarsening with averaged terrain elevation is a traditional solution that can significantly speed up inundation modeling, but the simplified coarsening approach fails to describe the detailed flood propagation process due to the building; hence, sub-grid models have been developed to account for building features in the coarse grid by obtaining additional parameters from the fine grid to increase the accuracy.

Many studies adopted the porosity treatment of the coarse grid in sub-grid models to simulate real flow conditions. Yu and Lane [4] used topographic variability in sub-grids to describe the blockage and flux effects, and comparing to traditional approaches, their method provided a better flood prediction for urban areas. McMillan and Brasington [5] produced the sub-grid parameter of the coarse grid by the depth-dependent porosity function from the volume-depth relationship. Chen et al. [6] applied the building coverage ratio (BCR) and conveyance reduction factors to reflect the geometry of buildings and alignment attributes in coarse grid modeling; These parameters in the study were further developed by the multi-layered approach [7].

Although accurate information on porosity improves the performance in urban inundation simulation, there is a growing concern in the drag effect of buildings from bed roughness modification. The IMPACT project [8] has proposed an approach of an increased friction-based representation of buildings and obstacles to explicitly introduce the presence of buildings in the computation model. Liang et al. [9] simulated the dam break flow through buildings by increasing the local roughness value. Soares-Frazao et al. [10] applied an equivalent roughness value in the shallow-water model with porosity to account for the building effect in large-scale flood plains. Sanders et al. [11] discussed how shear resistance and drag resistance affect flood propagation and used the uniform drag coefficient in the porous shallow water model to account for flow resistance of buildings in sub-grid buildings. Neelz and Pender [12] chose an appropriate roughness parameter of the coarse grid by using the fine-grid model as a benchmark to describe the building blockage effect in inundation models. A modification of roughness values is adopted in most research papers to reflect the increased resistance. Much research in recent years has focused on calibrating roughness values by experiment results $[10,13]$.

In this paper, steady-flow experiments are presented and performed in a rectangular channel to simulate the backwater effect and drag resistance due to the presence of buildings. Building drag resistance was discussed and expressed as Manning's roughness, and the relationship between different building occupancy and adjusted Manning's roughness was analyzed from experiment results and 
applied to the two-dimensional inundation model by considering building occupancy and Manning's roughness adjustment in the coarse grid.

\section{Methodology}

\subsection{Two-Dimensional Inundation Model}

Assuming that the acceleration of water flow on land surface is small compared with the gravitation and friction, the two-dimensional (2D) depth-averaged shallow water equations on land surface can be written as [14]

$$
\begin{aligned}
& \frac{\partial d}{\partial t}+\frac{\partial(u d)}{\partial x}+\frac{\partial(v d)}{\partial y}=q \\
& -\frac{\partial h}{\partial x}=u\left[\frac{n^{2} \sqrt{u^{2}+v^{2}}}{d^{4 / 3}}\right] \\
& -\frac{\partial h}{\partial y}=v\left[\frac{n^{2} \sqrt{u^{2}+v^{2}}}{d^{4 / 3}}\right]
\end{aligned}
$$

where Equation (1) is the continuity equation, and Equations (2) and (3) are momentum equations in Cartesian horizontal directions; $d$ is the depth of flow $(\mathrm{m}) ; h$ is the water stage $(\mathrm{m}) ; u$ and $v$ are the velocity component in $x$ and $y$ directions $(\mathrm{m} / \mathrm{s}) ; q$ is the source or the sink per unit area $(\mathrm{m} / \mathrm{s})$, and $n$ is Manning's roughness $\left(\mathrm{s} / \mathrm{m}^{1 / 3}\right)$.

The flow conditions in urban areas differ from in rural plains due to the densely distributed buildings. Buildings may occupy a partial area of a coarse grid cell, which reduces the storage capacity of the cell when the flood depth is below the threshold value. In this study, buildings were conceptualized as a square region located at the cell's center, as shown in Figure 1, without affecting the flux through the boundary shared with its neighbor cells. The fraction of the inactive area occupied by buildings that does not contribute to the flow in the area is defined as the building coverage ratio $\left(\mathrm{BCR}, \alpha_{0}\right)$, such that the flood water can only distribute to $1-\alpha_{0}$ of the area. Equation (1) is therefore modified as:

$$
\frac{\partial\left(1-\alpha_{0}\right) d}{\partial t}+\frac{\partial(u d)}{\partial x}+\frac{\partial(v d)}{\partial y}=q
$$

Figure 1. Schematic of simulation grid containing buildings.

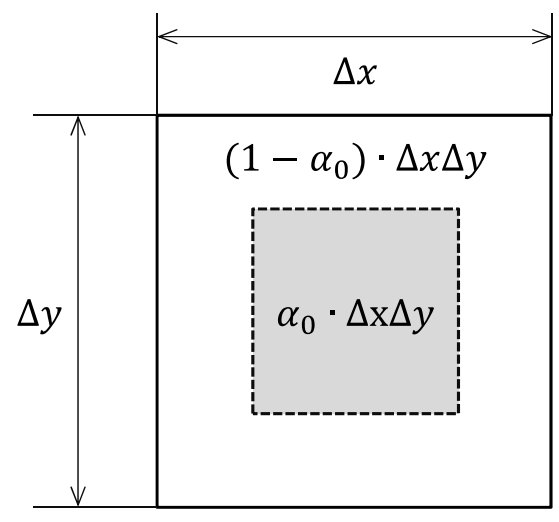

[-] Building

$\square$ Simulation Grid 


\subsection{The Resistance under the Blockage Effect of Buildings}

The total resistance $F$ within a computing cell includes the surface resistance $F^{\prime}$ along flow paths and the building drag resistance $F^{\prime \prime}$ due to the blockage of buildings:

$$
F=F^{\prime}+F^{\prime \prime}
$$

\subsubsection{The Surface Resistance}

The surface resistance is defined as the friction shearing stress on the ground surface area. The existence of buildings restricts the flow between buildings, which results in reduced friction forces due to a lower surface area $\left(1-\alpha_{0}\right) \cdot A$, thus, the surface resistance can be expressed as:

$$
F^{\prime}=\tau_{w} \cdot\left(1-\alpha_{0}\right) \cdot A
$$

where $\tau_{w}=\gamma \cdot d \cdot S_{f}$ is the friction shearing stress, and $\gamma$ is the specify weight of water. By replacing the friction slope $S_{f}$ with $\left(n_{0}^{2} \cdot V^{2}\right) / d^{4 / 3}$, where $V=\sqrt{u^{2}+v^{2}}$ and $n_{0}$ is Manning's roughness without considering the building effect, and substituting $\tau_{w}$ in Equation (6), the reduced resistance force becomes as follows:

$$
F^{\prime}=\gamma \cdot d \cdot \frac{n_{0}^{2} \cdot V^{2}}{d^{4 / 3}} \cdot\left(1-\alpha_{0}\right) \cdot A=\gamma \cdot d \cdot \frac{\left(n^{\prime}\right)^{2} \cdot V^{2}}{d^{4 / 3}} \cdot A
$$

where $n^{\prime}$ represents the Manning's roughness caused by the surface resistance $\left(\mathrm{s} / \mathrm{m}^{1 / 3}\right)$. The building drag resistance can be converted to the same form as the shear resistance applied to the total area:

$$
F^{\prime \prime}=\gamma \cdot d \cdot \frac{\left(n^{\prime \prime}\right)^{2} \cdot V^{2}}{d^{4 / 3}} \cdot A
$$

where $n^{\prime \prime}$ represents the Manning's roughness caused by building drag resistance $\left(\mathrm{s} / \mathrm{m}^{1 / 3}\right)$.

Substituting Equations (7) and (8) into Equation (5), we obtain the total friction force as follows:

$$
\gamma \cdot d \cdot \frac{n^{2} \cdot V^{2}}{d^{4 / 3}} \cdot A=\gamma \cdot d \cdot \frac{n_{0}^{2} \cdot V^{2}}{d^{4 / 3}} \cdot\left(1-\alpha_{0}\right) \cdot A+\gamma \cdot d \cdot \frac{\left(n^{\prime \prime}\right)^{2} \cdot V^{2}}{d^{4 / 3}} \cdot A
$$

where $n$ is the adjusted Manning's roughness for overland flow modeling that accounts for both the ground surface friction and the building shape drag. Therefore, the Manning's roughness corresponding to the blockage effect is obtained.

$$
n=\sqrt{\left(1-\alpha_{0}\right) \cdot n_{0}^{2}+\left(n^{\prime \prime}\right)^{2}}
$$

In Equation (13), the building drag resistance, $n$ ", was estimated by a flume experiment.

In this study, the non-inertia wave model which neglects the acceleration terms of water flow has been adopted for simulation, but the acceleration of water flow due to restriction of the buildings should be considered in building block. Therefore, the modified Manning's roughness according was applied to reflect the effect of acceleration terms. 


\subsubsection{Flume Model Experiment}

The building drag resistance leads to an energy loss due to the obstruction of flow. An experiment was established to quantify building drag resistance. The experiment was installed in a horizontal flume at Hydrotech Research Institute, National Taiwan University (Figure 2). The flume was a rectangular channel $1 \mathrm{~m}$ wide, $1.2 \mathrm{~m}$ high, and $37 \mathrm{~m}$ long, and the channel Manning's roughness coefficient was 0.05 , which is its factory designed value. Buildings were represented by 12 square plastic pillars fixed on a $1.00 \mathrm{~m}$ wide $\times 1.33 \mathrm{~m}$ long plate, as shown in Figure 3 . In this study, six BCRs $(0.04,0.16,0.25,0.36,0.49$ and 0.64$)$ were set by various sizes of pillars. Building block is defined as the sector of the channel where buildings are settled (Figure 4). For example, if BCR is 0.5, the total area of the pillar will be half of the building block's area.

Figure 2. Functional flume.

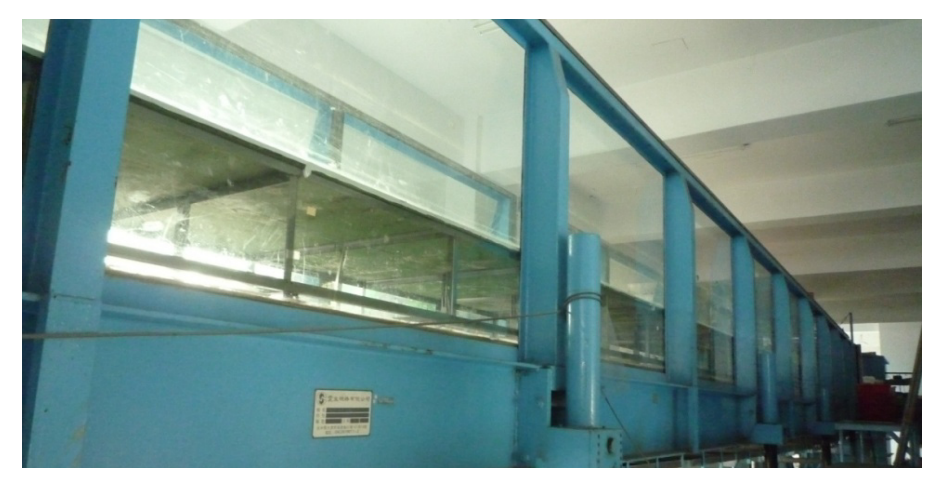

Figure 3. Building model represented by plastic pillars.

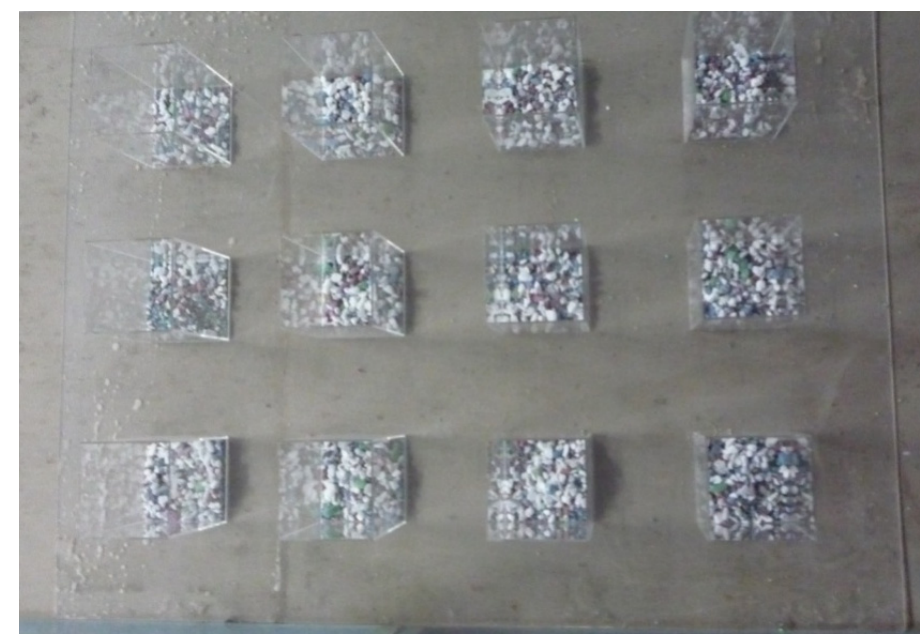

The flow in the flume was controlled as a constant discharge by an electric valve. Uniform flow conditions were established before the building block and a free overflow at the end of the flume was used to regulate the flow depth. The flow velocity was measured by a magnetic flow velocity meter, and velocity profiles were used to determine the mean velocity. The constant discharge of the flume can be calculated by flow velocity and water depth while no pillars are installed.

The upstream velocity and water depth were measured in the position where $x=3 \mathrm{~m}$ (Figure 5). The water flows into the building block while $x=4.13-5.46 \mathrm{~m}$, and the water stage changes rapidly 
due to the obstruction of buildings, we recorded totally nine sets of water depths and velocities each $17 \mathrm{~cm}$ to calculate the mean depth and velocity in the building block. The downstream velocity and water depth were measured in $x=7 \mathrm{~m}$.

Figure 4. Settlement of experiment.

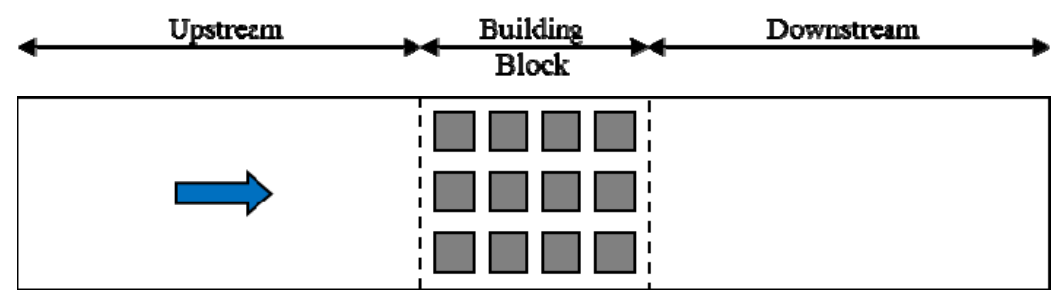

(Top view)

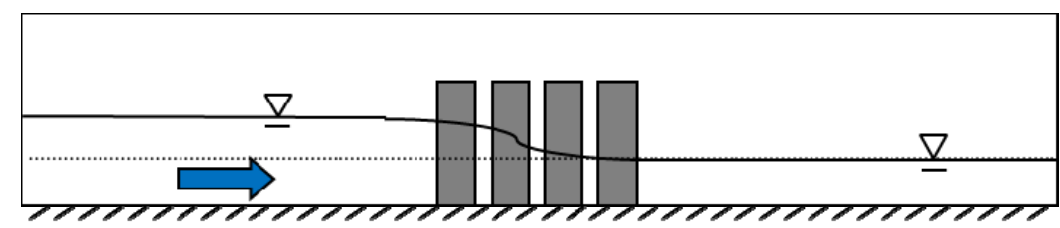

(Side view)

Plastic pillar

Figure 5. Measure positions of flow depth and velocity.
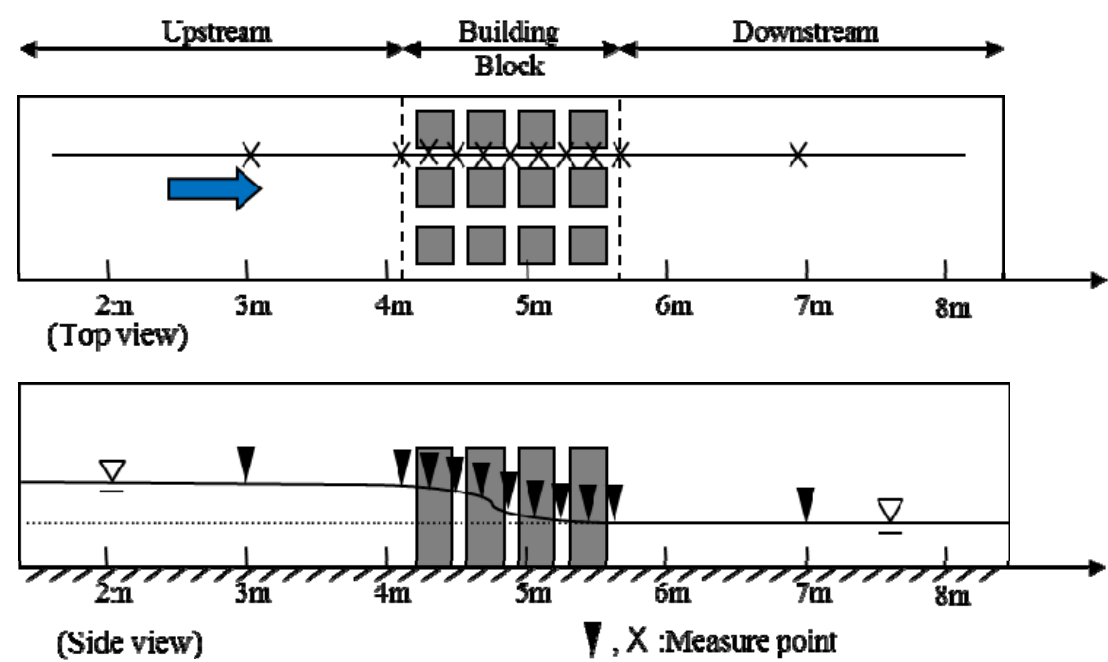

\section{Results and Discussion}

\subsection{Building Drag Resistance}

The flume was built in a smooth boundary channel so that the surface resistance is small compared with the drag resistance in the experiment. Assuming that the effect of surface resistance can be neglected, the experimental slope of the energy-grade line $\left(S_{f}^{\prime \prime}\right)$ contributed by drag resistance is expressed as follows:

$$
S_{f}^{\prime \prime}=\left(Y_{1}-Y_{2}\right) / \Delta x
$$

where $Y_{1}$ and $Y_{2}$ are the upstream and downstream water depth; whereas $\Delta x$ is the length of the building block $(1.33 \mathrm{~m})$. 
From Manning Equation, the experimental slope of the energy-grade line $\left(S_{f}^{\prime \prime}\right)$ due to the shape resistance can be used to obtain the experimental roughness, $n^{\prime \prime}$, which represents the building drag resistance:

$$
n^{\prime \prime}=\frac{\left(S_{f}^{\prime \prime}\right)^{1 / 2} \cdot d^{2 / 3}}{V}
$$

Considering the oscillation of water depth in the building block, $d$ is defined as the mean value of upstream and downstream depth, i.e., $d=\left(Y_{1}+Y_{2}\right) / 2$, and $V$ is also the mean value, $V=\left(V_{1}+V_{2}\right) / 2$.

Table 1 shows the mean water depth and velocity of each setting. While the upstream water depth $Y_{1}$ increases with BCR significantly, the downstream depth $Y_{2}$ remains unchanged. The results show that the downstream water depths remain unchanged, and there are only a few differences in downstream velocities. It indicates that the wave celerity is larger than the flow velocity in subcritical flow, i.e., the wave travels in upstream direction and induces the backwater effect.

Table 1. Water depths (unit: $\mathrm{cm}$ ) and velocities (unit: $\mathrm{cm} / \mathrm{s}$ ) in different building coverage ratio (BCRs).

\begin{tabular}{cccccccc}
\hline BCR $\left(\boldsymbol{a}_{\mathbf{0}}\right)$ & $\mathbf{0 . 0 0}$ & $\mathbf{0 . 0 4}$ & $\mathbf{0 . 1 6}$ & $\mathbf{0 . 2 5}$ & $\mathbf{0 . 3 6}$ & $\mathbf{0 . 4 9}$ & $\mathbf{0 . 6 4}$ \\
\hline Upstream mean water depth, $\mathrm{Y}_{1}$ & 8.50 & 8.80 & 9.00 & 9.30 & 9.55 & 10.20 & 11.70 \\
Downstream mean water depth, $\mathrm{Y}_{2}$ & 8.50 & 8.50 & 8.50 & 8.50 & 8.50 & 8.50 & 8.50 \\
Upstream mean water velocity, $\mathrm{V}_{1}$ & 13.74 & 13.33 & 13.25 & 12.59 & 12.29 & 11.53 & 9.85 \\
Downstream mean water velocity, $\mathrm{V}_{2}$ & 13.74 & 13.60 & 13.60 & 13.61 & 13.62 & 13.65 & 13.84 \\
\hline
\end{tabular}

We can calculate $V, d, S_{f}^{\prime \prime}$ under different BCR values shown in Table 2, and obtain $n^{\prime \prime}$ from Equation (12). The relationship between BCR and $n^{\prime \prime}$ is plotted in Figure 6. By polynomial regression we can obtain the experimental roughness $n^{\prime \prime}$ as below.

$$
n^{\prime \prime}=2.835 \alpha_{0}^{3}-2.629 \alpha_{0}^{2}+0.969 \alpha_{0}
$$

According to Equations (10) and (13), the roughness corresponding to the blockage effect can be obtained.

$$
n=\sqrt{\left(1-\alpha_{0}\right) \cdot n_{0}^{2}+\left(2.835 \alpha_{0}^{3}-2.629 \alpha_{0}^{2}+0.969 \alpha_{0}\right)^{2}}
$$

Different value of $n_{0}$ and BCR were inputted into Equation (14) to observe the relationship of BCR and $n$, as shown in Figure 7. It can be seen that roughness generally increased with BCR. For example, roughness $n$ increased mildly with BCR, but rapidly when BCR is greater than 0.45 . The trend shows that surface resistance dominates the change of roughness when BCR is small. With increasing BCR, first roughness increased markedly and then, when BCR is close to 0.64, it remains approximately constant close to the value of 0.3 . Further, this analysis indicates that BCR is the main factor influencing roughness for larger values of BCR.

Table 2. Water depths in different BCRs (unit: $\mathrm{cm}$ ).

\begin{tabular}{cccccccc}
\hline BCR $\left(\boldsymbol{\alpha}_{\mathbf{0}}\right)$ & $\mathbf{0 . 0 0}$ & $\mathbf{0 . 0 4}$ & $\mathbf{0 . 1 6}$ & $\mathbf{0 . 2 5}$ & $\mathbf{0 . 3 6}$ & $\mathbf{0 . 4 9}$ & $\mathbf{0 . 6 4}$ \\
\hline$V$ & 13.74 & 13.46 & 13.43 & 13.10 & 12.95 & 12.59 & 11.85 \\
$d$ & 8.50 & 8.65 & 8.75 & 8.90 & 9.03 & 9.35 & 10.10 \\
$S_{f}^{\prime \prime}$ & 0.00000 & 0.00226 & 0.00376 & 0.00602 & 0.00789 & 0.01278 & 0.02406 \\
$n^{\prime \prime}$ & 0.000 & 0.069 & 0.090 & 0.118 & 0.138 & 0.185 & 0.284 \\
\hline
\end{tabular}


Figure 6. Relationship between $n^{\prime \prime}$ and BCR.

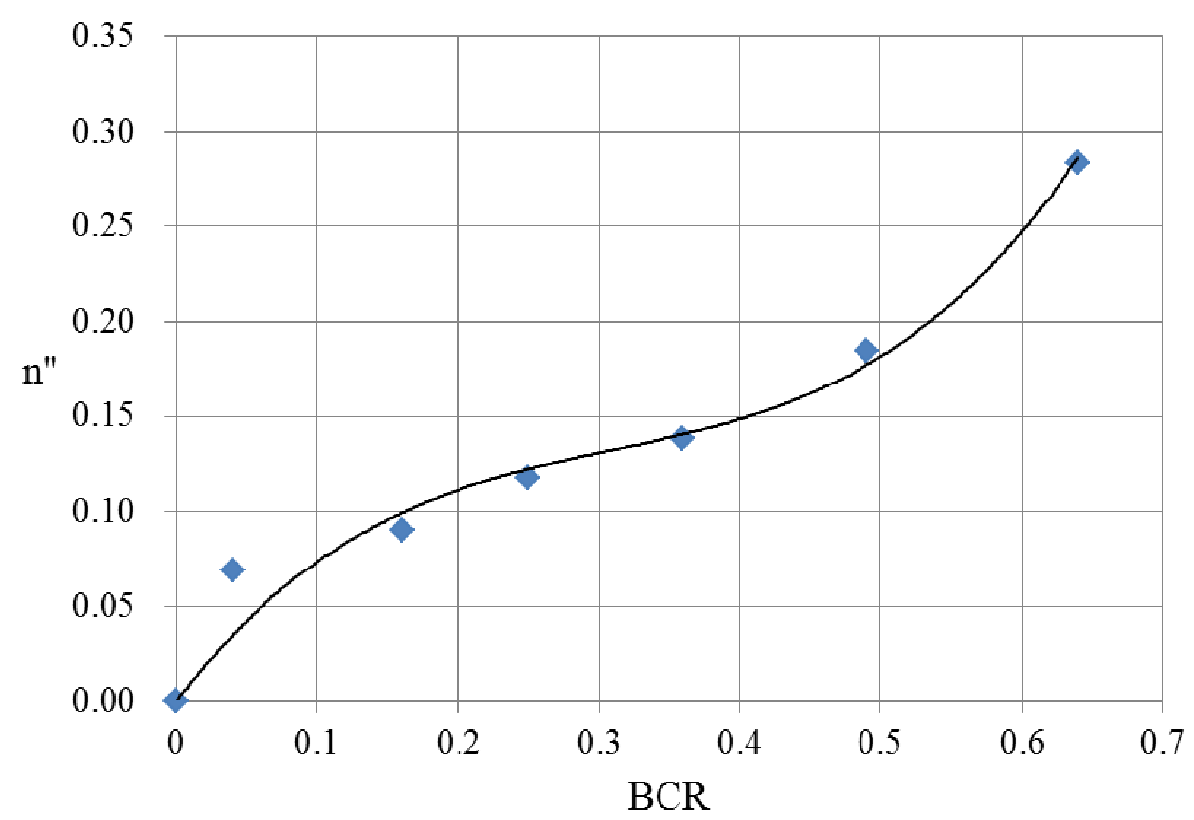

Figure 7. Relationship between $n$ and BCR under different $n_{0}$.

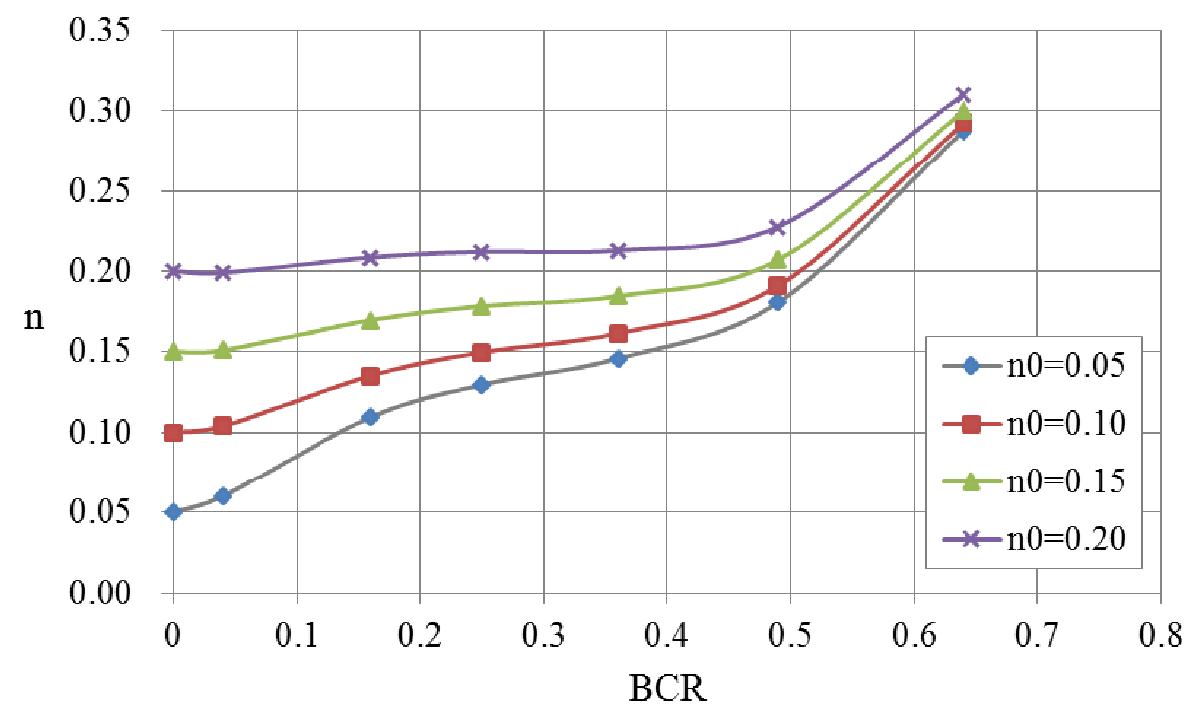

\subsection{Scale Adjustment}

Due to scale differences between the experiment and urban areas, roughness corresponding to the blockage effect in Equation (14) was modified by scale adjustment to allow applications in urban inundation modeling.

The ratio of simulation roughness of the urban area scale to the experimental scale $\left(n_{r}^{\prime \prime}\right)$ can be expressed as:

$$
n_{r}^{\prime \prime}=\frac{\left(S_{f r}\right)^{1 / 2} \cdot d_{r}^{2 / 3}}{V_{r}}
$$


where $S_{f r}$ is the ratio of the slope of energy-grade line, $d_{r}$ is the ratio of water depth $\left(d_{r}=d / 0.085\right)$, and $V_{r}$ is the ratio of flow velocity.

While water flow passes through buildings, systematic and sudden widening and narrowing may occur. The slope of the energy-grade line in the longitudinal direction of the flow can be determined by Borda's formula [10]

$$
S_{f}=\frac{k \cdot V^{2}}{L}
$$

where the length $L$ is the spatial typical scale of the widening and narrowing (i.e., the grid side), and $k$ is the head loss coefficient.

Thus the ratio of the slope of energy-grade line is:

$$
S_{f r}=\frac{V_{r}^{2}}{L_{r}}
$$

where $L_{r}$ is the ratio of the simulation grid cell size to the experimental grid cell size $\left(L_{r}=\Delta x / 0.33\right)$.

By substituting $S_{f r}$ of Equation (17) into Equation (15), the ratio of roughness $n_{r}^{\prime \prime}$ can be obtained.

$$
n_{r}^{\prime \prime}=\frac{d_{r}^{2 / 3}}{L_{r}^{1 / 2}}
$$

Experimental roughness $n^{\prime \prime}$ in Equation (14) has to be modified with $n_{r}^{\prime \prime}$ to represent the roughness in the urban inundation simulation.

$$
n=\sqrt{\left(1-\alpha_{0}\right) \cdot n_{0}^{2}+\left(n_{r}^{\prime \prime}\right)^{2} \cdot\left(2.835 \alpha_{0}^{3}-2.629 \alpha_{0}^{2}+0.969 \alpha_{0}\right)^{2}}
$$

\subsection{Model Validation}

\subsubsection{Experimental Scale}

To discuss the application of experiment results of adjusted Manning's roughness, a numerical simulation of 2D inundation model was employed to simulate the blockage effect. In the 2D inundation model, BCR was used in continuity Equation (4) to account for building blockage in overland flow, and the adjusted Manning's roughness was applied in momentum Equations (2) and (3) to reflect the flow resistance result from buildings.

The conveyance of cross section and building shape resistance caused by buildings in channel will induce a backwater effect. This research established a $0.99 \mathrm{~m} \times 6.6 \mathrm{~m}$ area, as shown in Figure 8 , by using the $0.33 \mathrm{~m}$ grid resolution and verified the effect of building blockage on the flow mechanisms in the hydraulic experiment. A total of 12 building cells were set to covering the building block, and the terrain slope was 0.001 descending from the upstream to downstream. The initial Manning's roughness $n_{0}$ was 0.05 , and this value was also the same as the experiment setting of the hydraulic flume. The inflow was uniformly inputted in upstream cells as upper boundary conditions, and the downstream boundary was considered as a free weir flow. 
Figure 8. Simulation grid of 2D inundation model in experiment scale.

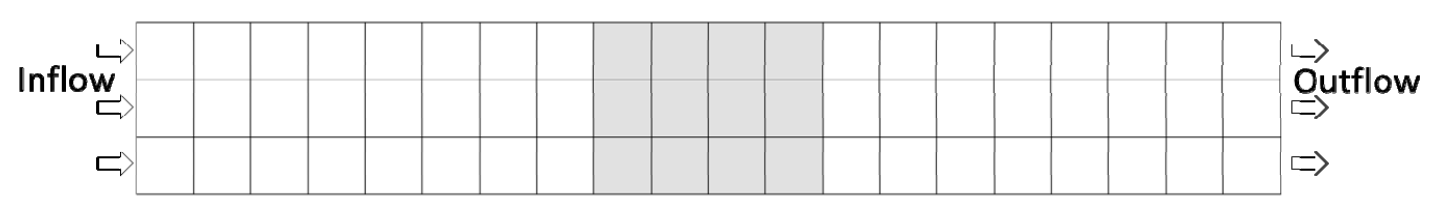

Grid of building block

The BCR of building grid was set as $\alpha_{0}$ in the inundation model, and Manning's roughness of each building cell was calculated by mean of Equation (14) according to its BCR and $n_{0}$. The adjusted Manning's roughness of each BCR is listed in Table 3. The surface resistance becomes smaller with increaseing BCR, but the adjusted Manning's roughness is getting larger because of the building shape resistance. The results indicate that buildings can reduce the surface area of water flow while building obstruction mainly affects the change of Manning's roughness.

Table 3. Roughness under different BCRs.

\begin{tabular}{cccccccc}
\hline BCR $\left(\boldsymbol{\alpha}_{\mathbf{0}}\right)$ & $\mathbf{0}$ & $\mathbf{0 . 0 4}$ & $\mathbf{0 . 1 6}$ & $\mathbf{0 . 2 5}$ & $\mathbf{0 . 3 6}$ & $\mathbf{0 . 4 9}$ & $\mathbf{0 . 6 4}$ \\
\hline$n^{\prime}$ & 0.050 & 0.048 & 0.042 & 0.038 & 0.032 & 0.026 & 0.018 \\
$n^{\prime \prime}$ & 0.000 & 0.035 & 0.099 & 0.122 & 0.140 & 0.177 & 0.286 \\
$n$ & 0.050 & 0.059 & 0.107 & 0.127 & 0.143 & 0.179 & 0.287 \\
\hline
\end{tabular}

The inundation simulations were carried out with modified Manning's roughness under different BCRs to show the backwater effect caused by buildings. The comparisons of differences between upstream and downstream water depth $\left(Y_{1}-Y_{2}\right)$ of simulation results and experiment records are listed in Table 4. From the simulation results, we can see that the backwater effect is more significant while BCR gets larger, however, errors between the experiment and the simulation water depth remain in small values. The profile of water depth under different BCRs is plotted in Figures 9-11, one can find that in the building block, the results are not good in term of water surface profile. In the experiment, the water depth varies significantly in building block due to the acceleration of the water flow while widening and narrowing. In simulation results of a 2D inundation model, we neglecting the acceleration terms, thus, water depth in building block descends smoothly while water passed through the building block in all cases. However, the upstream and downstream water depth are very consistent between the experiment and simulation results, which means that applying the adjusted Manning's roughness in the $2 \mathrm{D}$ inundation model can adequately describe energy losses caused by the building blockage effect.

Table 4. Comarisons of difference between upsream and downstream water depth of experiment and simulation results.

\begin{tabular}{cccccccc}
\hline BCR $\left(\boldsymbol{\alpha}_{\mathbf{0}}\right)$ & $\mathbf{0}$ & $\mathbf{0 . 0 4}$ & $\mathbf{0 . 1 6}$ & $\mathbf{0 . 2 5}$ & $\mathbf{0 . 3 6}$ & $\mathbf{0 . 4 9}$ & $\mathbf{0 . 6 4}$ \\
\hline$Y_{1}-Y_{2}$ in Experiment $(\mathrm{cm})$ & 0.0 & 0.3 & 0.5 & 0.7 & 1.05 & 1.7 & 3.2 \\
$Y_{1}-Y_{2}$ in Simulation $(\mathrm{cm})$ & 0.08 & 0.17 & 0.82 & 0.99 & 1.18 & 1.73 & 3.42 \\
Error $(\mathrm{cm})$ & 0.08 & -0.13 & 0.32 & 0.29 & 0.13 & 0.03 & 0.22 \\
\hline
\end{tabular}


Figure 9. Water profile of experiment and simulation results $\left(\alpha_{0}=0.36\right)$.

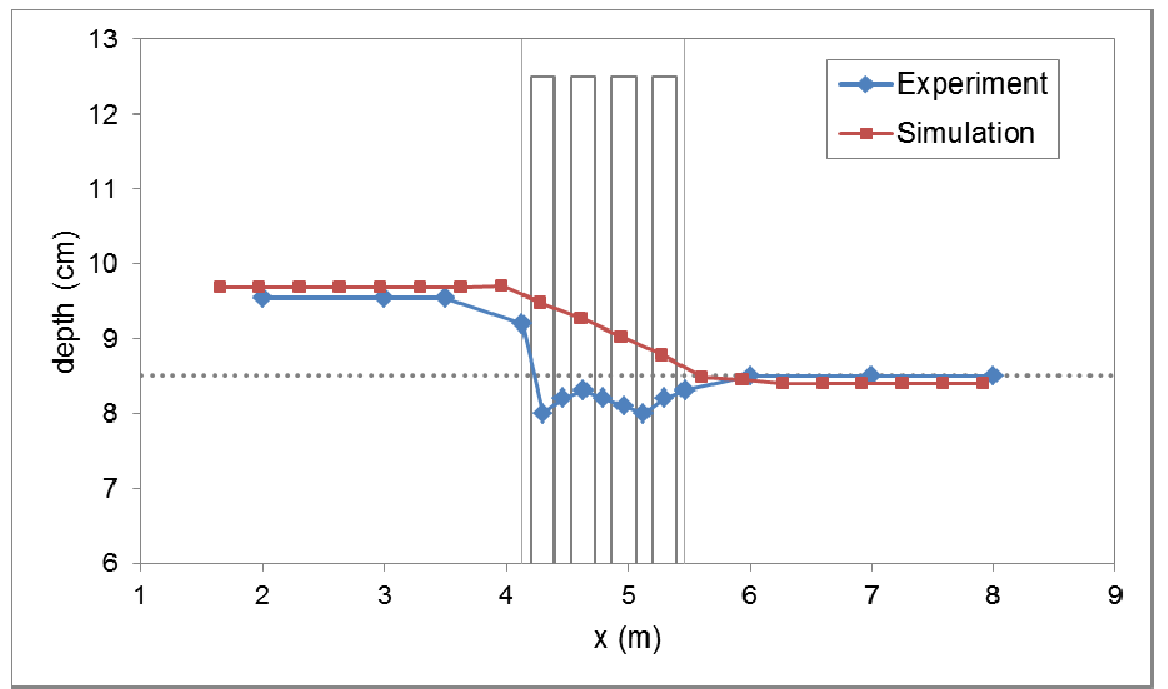

Figure 10. Water profile of experiment and simulation results $\left(\alpha_{0}=0.49\right)$.

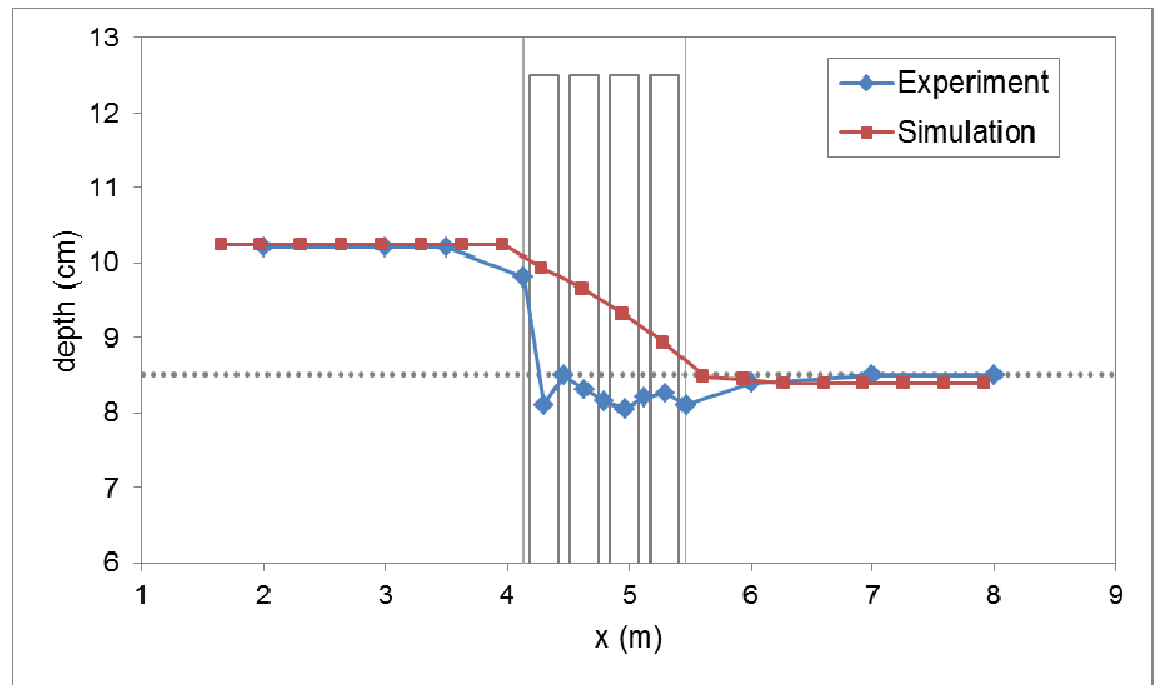

Figure 11. Water profile of experiment and simulation results $\left(\alpha_{0}=0.64\right)$.

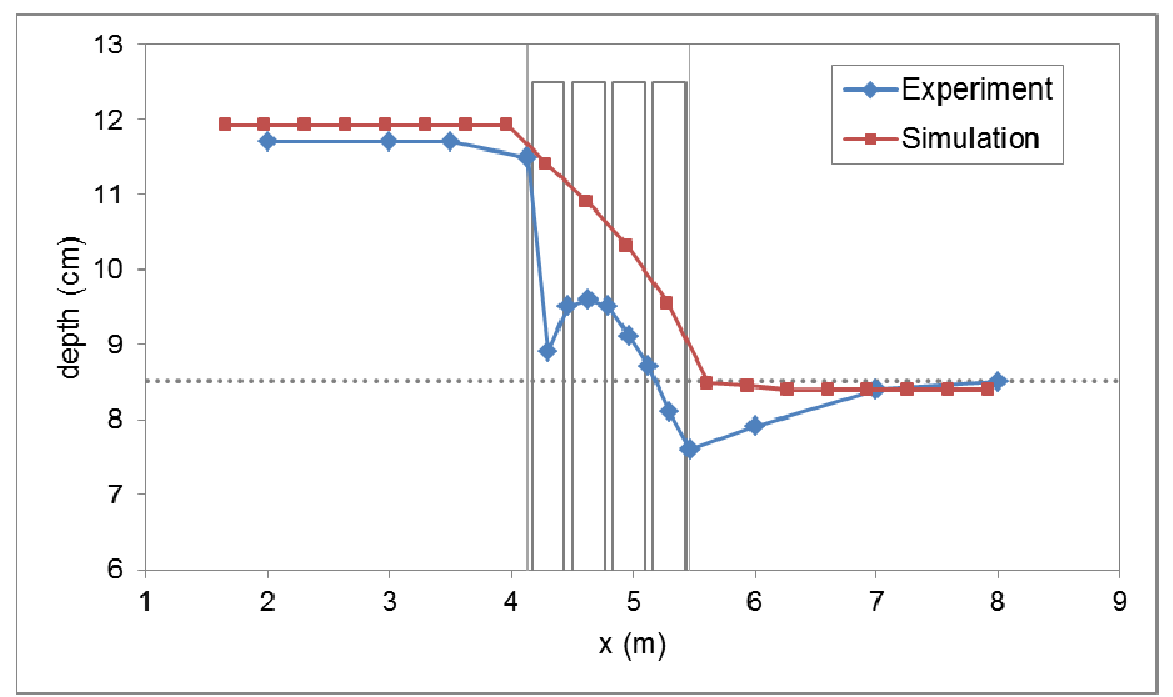




\subsubsection{Real Scale}

Because the hydraulic experiment is unable to reveal the actual size of urban areas, thus, the 2D inundation model was also used to simulate inundation under roughness adjustment in urban areas. The simulation area was $330 \mathrm{~m} \times 99 \mathrm{~m}$, and the terrain slope 0.001 and Manning's roughness $n_{0}=0.05$ were the same as in the flume experiment. The inflow was also a uniform flow and the outflow was a free weir flow.

Figure 12 shows that the simulation area was covered by the a fine grid formed by as many as 3000 $(3.3 \mathrm{~m} \times 3.3 \mathrm{~m})$ square cells, as well as by a coarse grid formed by only $30(33 \mathrm{~m} \times 33 \mathrm{~m})$ cells. Therefore, each cell of the coarse grid contains 100 cells of the fine grid. The central 12 coarse-grid were selected to represent buildings by the BCR setting, whereas buildings were represented by means of cells with a higher elevation in the fine grid simulation. For example, the elevations of the 64 fine grid cell were set to a higher value to represent $\mathrm{BCR}=0.64$ in the coarse grid. In the coarse grid simulation, the case of no buildings $(\mathrm{BCR}=0)$ was firstly simulated to obtain the average water depth $0.54 \mathrm{~m}$, so $d_{r}=6.35$ can be calculated from the average water depth $0.085 \mathrm{~m}$ in the experiment. The roughness was modified by means of Equation (19) with $n_{r}^{\prime \prime}=0.34$ and $L_{r}=100$. The total simulation time was $24 \mathrm{~h}$ in both the fine and the coarse grids. The time step was $0.01 \mathrm{~s}$ in the fine grid and $0.1 \mathrm{~s}$ in the coarse grid.

Figure 12. Simulation grid of $2 \mathrm{D}$ inundation model in real scale.

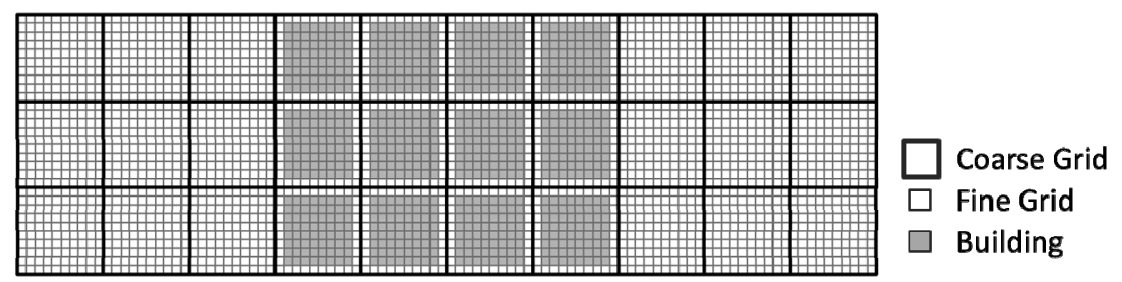

Figure 13 shows the simulation results of the water profile when $\mathrm{BCR}=0.36$. The higher water depths produced by the backwater effect in the coarse grid simulation were close to those in the fine grid. The result indicates that roughness adjustment can reflect building blockages, but differences in water depth would increase with a higher BCR, as can be seen in Figures 14 and 15. The water depth of the coarse grid was underestimated because the water depth was much greater than $0.54 \mathrm{~m}$, which was used to calculate the adjusted roughness in Equation (19). The average water depths of the coarse grid in the building area were $0.67 \mathrm{~m}\left(\alpha_{0}=0.49\right)$ and $\left.0.78 \mathrm{~m} \alpha_{0}=0.64\right)$, and instead of $0.54 \mathrm{~m}$, these values were applied to the roughness adjustment in Equations (18) and (19). The underestimation of water depth has been improved when the simulated water depths were used to account for the roughness adjustment, as shown in Figures 14 and 15. Hence, the simulated water depth will be used to roughness modification in each time step for further applications.

\subsection{Model Application}

Taichung City in middle Taiwan has Dakeng Mountain on the east side and Dadu in the west side. Figure 16 shows the topography and administrative borders of Taichung City. Taichung is a basin with the lowland in its southwest area. In the south, there are the Dali River and Wu River. The railway 
goes through the downtown, and the highway gets across the city along the Fazih River. The convenient traffic network consists of several importantly expressed ways, which encourage the centralization of the urban population.

Figure 13. Water profile of experiment and simulation results in real scale $\left(\alpha_{0}=0.36\right)$.

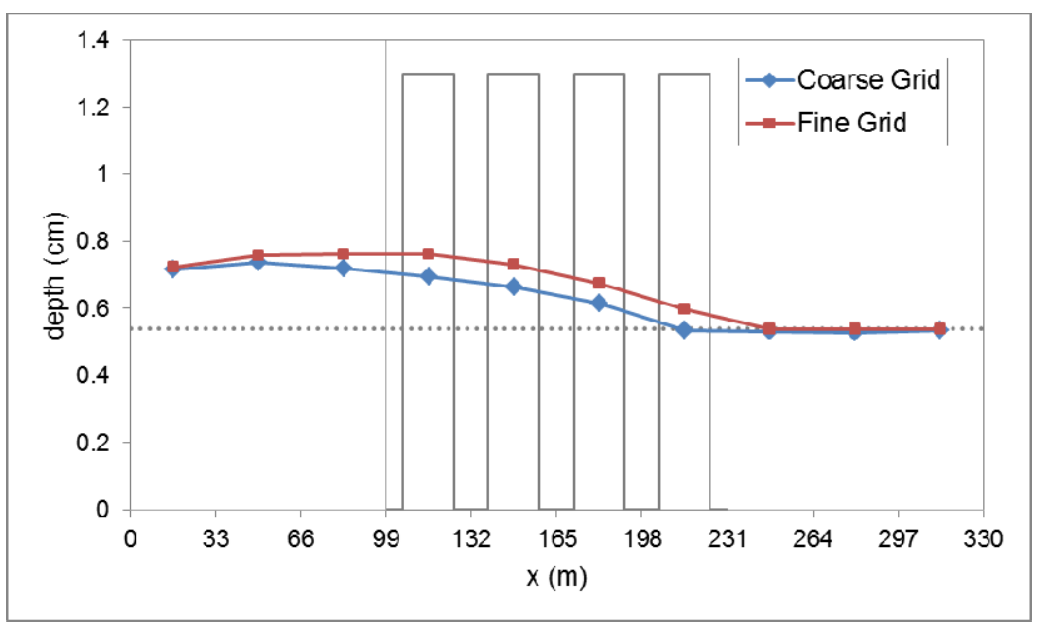

Figure 14. Water profile of experiment and simulation results in real scale $\left(\alpha_{0}=0.49\right)$.

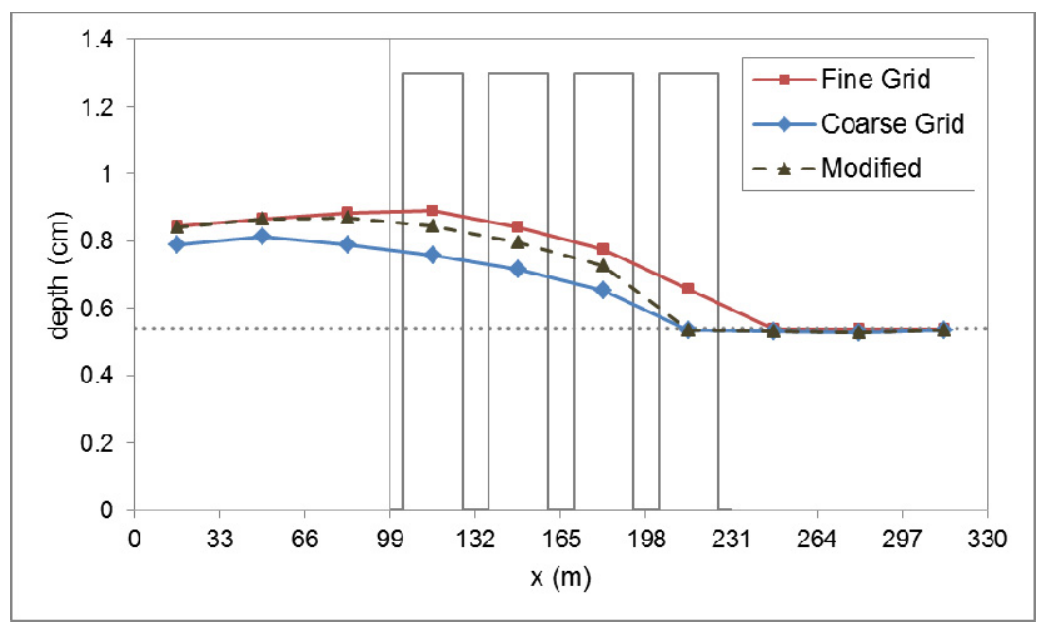

Figure 15. Water profile of experiment and simulation results in real scale $\left(\alpha_{0}=0.64\right)$.

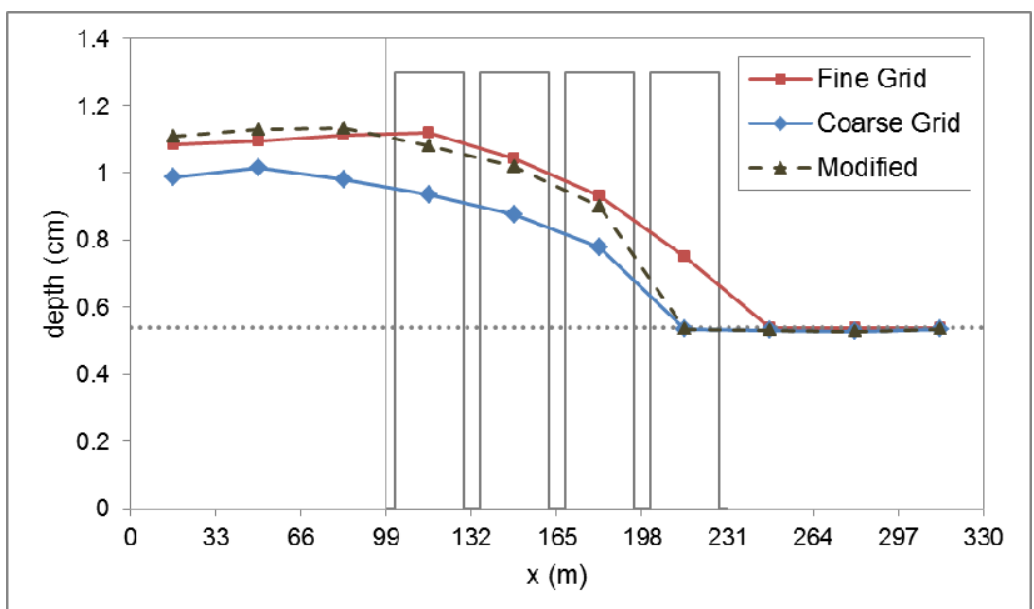


Figure 16. Elevation, water system, and sewer manholes of Taichung city.

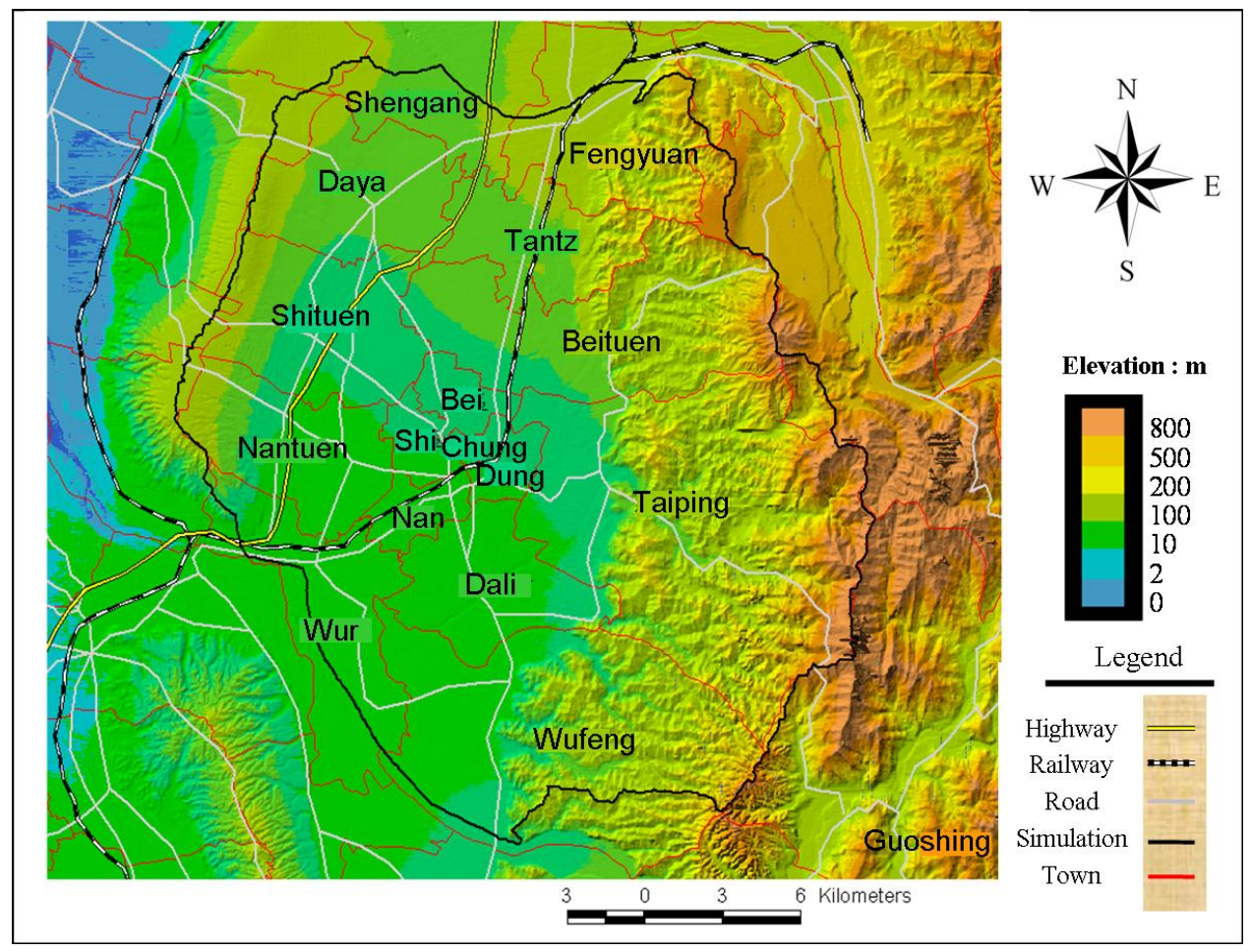

There are 174 sewers and 2018 manholes in Taichung City. Figure 17 shows the distribution of the sewer manholes. In the sewer system, the pipe diameter is $600 \mathrm{~mm}$. From higher to lower pipes, the diameter increases up to $2000 \mathrm{~mm}$.

Figure 17. Distribution of the sewer manholes of Taichung city.

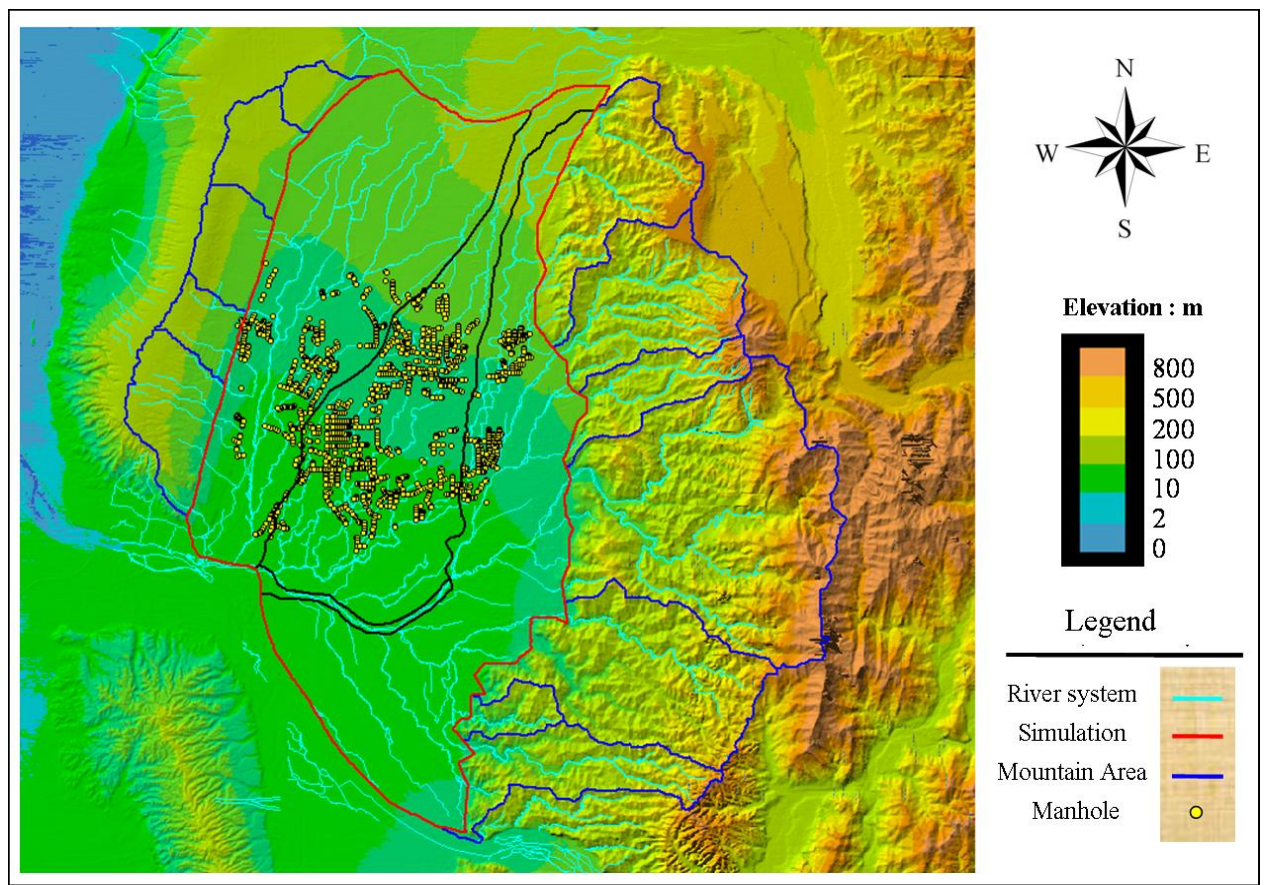

Typhoon Kalmaegi in 2008 was adopted for model application. Typhoon Kalmaegi intruded Taichung on 17 July 2008. Table 5 shows the total amount and peak intensity of $24 \mathrm{~h}$ rainfall from 
17 July 2008, 23:00, to 18 July 2008, 22:00. The peak intensity of most rain gauges exceeded the design standard $(73 \mathrm{~mm} / \mathrm{h})$ of the sewer system in Taichung City.

Table 5. Total amount and peak intensity of rainfall of Typhoon Kalmaegi in Taichung City.

\begin{tabular}{ccc}
\hline Rain gauge & Total rainfall $(\mathbf{m m})$ & Peak intensity $\mathbf{( m m} / \mathbf{h})$ \\
\hline Taichung & 478.9 & 120.0 \\
Dadu & 363.0 & 79.0 \\
Shhigang & 341.0 & 74.5 \\
Dakeng & 607.0 & 149.0 \\
Chungchulin & 567.0 & 91.0 \\
Tonlin & 409.5 & 82.5 \\
Shengang & 225.5 & 49.5 \\
Fenyuan & 377.5 & 78.5 \\
Changhua & 248.0 & 52.0 \\
Caotun & 295.0 & 71.0 \\
\hline
\end{tabular}

The HEC-1 Model developed by the U.S. Army Corps of Engineers [15] was used to calculate runoffs of the upstream catchments that in turn can be used as lateral inflows in the 2D inundation model. The Storm Water Management Model (SWMM) [16] was adopted to solve the sewer system in Taichung City. The discharges drained by pumping stations are considered as the lateral outflows of the model, and the surcharges of manholes are regarded as point sources in the model [17].

We compared two cases for reflecting building blockages in urban flood modeling with $80 \mathrm{~m} \times 80 \mathrm{~m}$ cells. Case 1 only adopted the bare terrain elevation without roughness adjustment, and it is the traditional approach in urban flood modeling. The original Manning's roughness of each grid cell was assumed according the land-use type of each cell and classified into the following three categories: 0.1 (waterway), 0.13 (agricultural, residential and traffic uses), and 0.20 (commercial and industrial uses). In Case 2, BCR values and adjusted roughness were used to represent the blockage effect. The BCR values were calculated from the occupied area of buildings in each cell. The Manning's roughness of each cell was modified according to Equation (19) during the simulation. The average BCR values of all districts listed in Table 6 are mean BCR values of all the cells located in the districts.

Table 6. Inundation area of Taichung City (unit: ha).

\begin{tabular}{cccc}
\hline District & Case 1 & Case 2 & Average BCR \\
\hline Situn & 638.08 & 705.28 & 0.22 \\
Nantun & 556.80 & 566.40 & 0.20 \\
Beitun & 424.32 & 550.40 & 0.26 \\
East & 186.24 & 255.36 & 0.36 \\
South & 283.52 & 305.92 & 0.34 \\
West & 222.72 & 246.30 & 0.41 \\
North & 166.40 & 213.76 & 0.43 \\
Central & 27.52 & 33.92 & 0.53 \\
\hline Total & 2505.60 & 2877.34 & \\
\hline
\end{tabular}


Figure 18 shows the simulated flooded area of Case 2 and investigated flooded area for Typhoon Kalmaegi surveyed by Taichung City Government. The torrential rainfall caused serious flood damage in Taichung city. The severe inundated area in Situn, Nantun, South, and East district can be simulated from the inundation model. The total inundation area was the summation of water depth above $0.5 \mathrm{~m}$ and shown in Table 6. It can be found that according to the modifications of the surface roughness value with BCR, the inundated area was obviously increased from 2506 to 2877 ha due to densely distributed buildings. The inundation area of all districts had the same trend. The inundation areas of each district are shown in Table 7. It is noted that the Nantun district had the smallest average BCR and the inundated area increased from 556.8 ha to 566.4 ha, which is an increase of about $1.7 \%$. The Central district had the highest BCR and the increased ratio of inundated area reached 23.26\%, which means that the water spread wider due to the existence of buildings. These results indicated that the blockage effect was more significant when the building occupancy on the surface was higher. From the results we can conclude that flood area increased due to the blockage effect of buildings, which indicates the flash flood in urban area will induce the severe inundation area and cause higher impact.

Figure 18. Simulated and investigated flooded areas of Typhoon Kalmaegi with building blockage effect (Case 2).

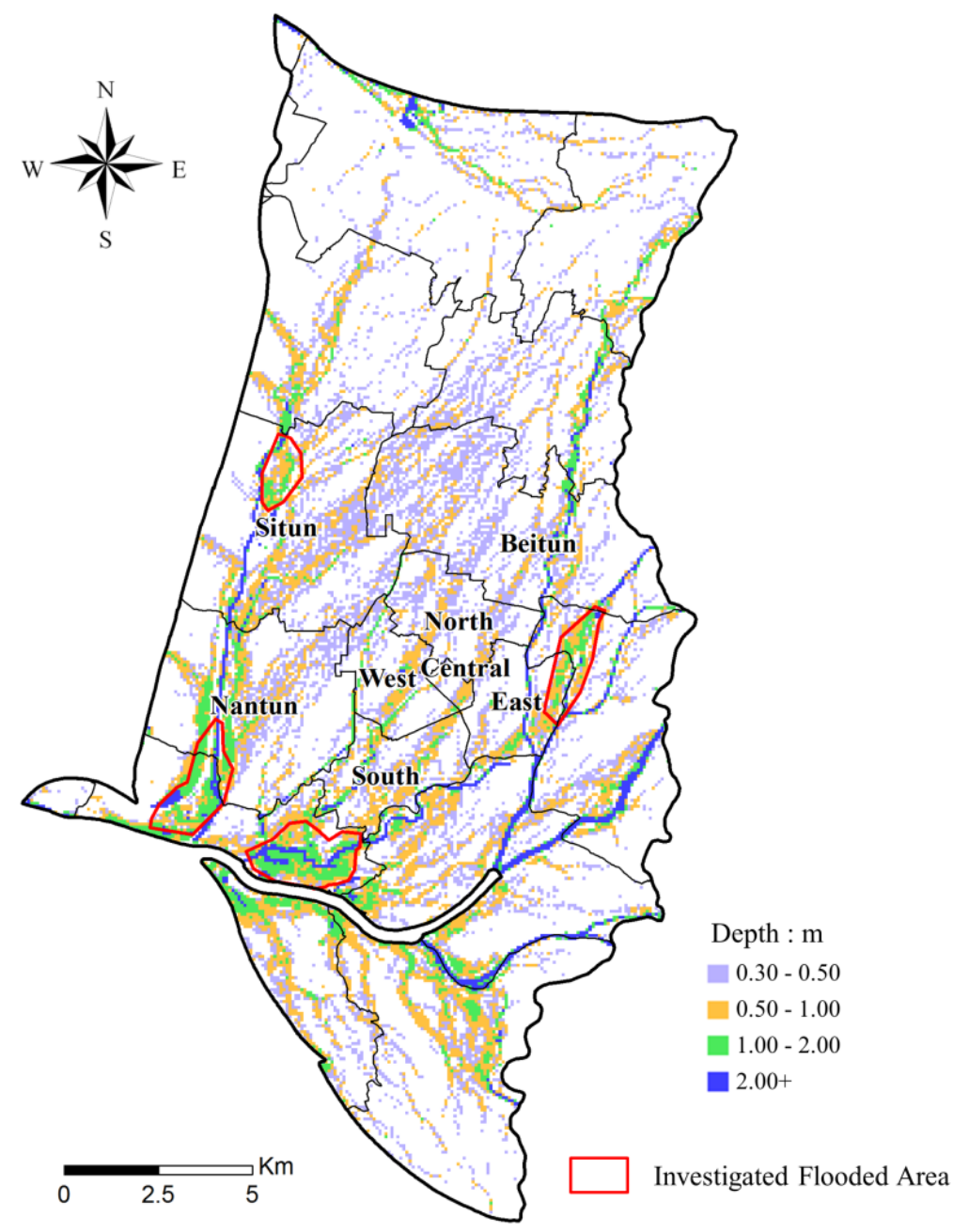


Table 7. Inundation area of each districts of Taichung City (unit: ha).

\begin{tabular}{|c|c|c|c|c|c|c|c|c|}
\hline \multirow{2}{*}{ Depth (m) } & \multicolumn{2}{|c|}{ Situn } & \multicolumn{2}{|c|}{ Nantun } & \multicolumn{2}{|c|}{ Beitun } & \multicolumn{2}{|c|}{ East } \\
\hline & Case 1 & Case 2 & Case 1 & Case 2 & Case 1 & Case 2 & Case 1 & Case 2 \\
\hline $0.5-1.0$ & 453.76 & 500.48 & 339.20 & 349.44 & 345.60 & 437.76 & 131.84 & 139.52 \\
\hline $1.0-2.0$ & 126.08 & 144.00 & 176.00 & 176.00 & 32.64 & 66.56 & 52.48 & 89.60 \\
\hline $2.0-3.0$ & 34.56 & 36.48 & 8.96 & 8.32 & 28.80 & 26.88 & 1.28 & 11.52 \\
\hline above 3.0 & 23.68 & 24.32 & 32.64 & 32.64 & 17.28 & 19.20 & 0.64 & 14.72 \\
\hline Total & 638.08 & 705.28 & 556.80 & 566.40 & 424.32 & 550.40 & 186.24 & 255.36 \\
\hline \multirow{2}{*}{ Depth (m) } & \multicolumn{2}{|c|}{ South } & \multicolumn{2}{|c|}{ West } & \multicolumn{2}{|c|}{ North } & \multicolumn{2}{|c|}{ Central } \\
\hline & Case 1 & Case 2 & Case 1 & Case 2 & Case 1 & Case 2 & Case 1 & Case 2 \\
\hline $0.5-1.0$ & 201.60 & 216.32 & 128.00 & 140.47 & 159.36 & 198.40 & 22.40 & 20.48 \\
\hline $1.0-2.0$ & 61.44 & 69.12 & 69.76 & 72.23 & 6.40 & 14.72 & 5.12 & 13.44 \\
\hline $2.0-3.0$ & 18.56 & 17.92 & 10.24 & 17.28 & 0.64 & 0.64 & 0.00 & 0.00 \\
\hline above 3.0 & 1.92 & 2.56 & 14.72 & 16.32 & 0.00 & 0.00 & 0.00 & 0.00 \\
\hline Total & 283.52 & 305.92 & 222.72 & 246.30 & 166.40 & 213.76 & 27.52 & 33.92 \\
\hline
\end{tabular}

\section{Conclusions}

The inundation model was developed to represent the effects of building blockage in urban areas. In this paper, we proposed a Manning's roughness modification method according to the blockage effect of buildings. The simulation results from Kalmaegi Typhoon indicated that the proposed model, using the BCR and the modified Manning's roughness, can produce more accurate results in urban inundation modeling.

\section{Acknowledgments}

The study was supported by the National Science Council, Taiwan, R.O.C. Valuable information and historical records were provided by the Central Weather Bureau and the Water Resources Agency. The authors are grateful for their considerable help.

\section{Author Contributions}

The concept of this paper was developed by Ming-Hsi Hsu. The hydraulic experiment and data analysis were undertaken by Yen-Hsiang Wang. The simulation of inundation model was conducted by Yen-Hsiang Wang and Chen-Jia Huang with the supervision of Ming-His Hsu and Wei-Hsien Teng. The first draft of the article was written by Chen-Jia Huang and was revised by the other authors.

\section{Conflicts of Interest}

The authors declare no conflict of interest.

\section{References}

1. Erpicum, S.; Dewals, B.; Archambeau, P.; Detrembleur, S.; Pirotton, M. Detailed inundation modelling using high resolution DEMs. Eng. Appl. Comput. Fluid Mech. 2010, 4, 196-208. 
2. Tsubaki, R.; Fujita, I. Unstructured grid generation using LiDAR data for urban flood inundation modelling. Hydrol. Process. 2010, 24, 1404-1420.

3. Yu, D.; Lane, S.N. Urban fluvial flood modelling using a two-dimensional diffusion-wave treatment, part 1: Mesh resolution effects. Hydrol. Process. 2006, 20, 1541-1565.

4. Yu, D.; Lane, S.N.; Urban fluvial flood modelling using a two-dimensional diffusion-wave treatment, part 2: Development of a sub-grid-scale treatment. Hydrol. Process. 2006, 20, 1567-1583.

5. McMillan, H.K.; Brasington, J. Reduced complexity strategies for modelling urban floodplain inundation. Geomorphology, 2007, 90, 226-243.

6. Chen, A.S.; Evans, B.; Djordjevic, S.; Savic, D.A. A coarse-grid approach to representing building blockage effects in 2D urban flood modelling. J. Hydrol. 2012, 426, 1-16.

7. Chen, A.S.; Evans, B.; Djordjevic, S.; Savic, D.A. Multi-layered coarse grid modelling in 2D urban flood simulations. J. Hydrol. 2012, 470, 1-11.

8. Alcrudo, F. Mathematical Modelling Techniques for Flood Propagation in Urban Areas; IMPACT Project Technical Report IMPACT Project WP3; Flood Propagation: Zaragoza, Spain, 2004.

9. Liang, D.F.; Falconer, R.A.; Lin, B.L. Coupling surface and subsurface flows in a depth averaged flood wave model. J. Hydrol. 2007, 337, 147-158.

10. Soares-Frazao, S.; Lhomme, J.; Guinot, V.; Zech, Y. Two-dimensional shallow-water model with porosity for urban flood modelling. J. Hydraul. Res. 2008, 46, 45-64.

11. Sanders, B.F.; Schubert, J.E.; Gallegos, H.A. Integral formulation of shallow-water equations with anisotropic porosity for urban flood modeling. J. Hydrol. 2008, 362, 19-38.

12. Neelz, S.; Pender, G. Parameterisation of square-grid hydrodynamic models of inundation in the urban area. In Proceedings of the Congress-International Association for Hydraulic Research, Venice, Italy, 1-6 July 2007; Volume 1, pp. 41-50.

13. Velickovic, M.; Van Emelen, S.; Zech, Y.; Soares-Frazão, S. Shallow-water model with porosity: Sensitivity analysis to head losses and porosity distribution. In River Flow 2010; Dittrich, A., Koll, K., Aberle, J., Geisenhainer, P., Eds.; Bundesanstalt für Wasserbau: Braunschweig, Germany, 2010; pp. 613-620.

14. Chang, T.J.; Hsu, M.H.; Teng, W.H.; Huang, C.J. A GIS-assisted distributed watershed model for simulating flooding and inundation. J. Am. Water Resour. Assoc. 2000, 36, 975-988.

15. U.S. Army Corps of Engineers, H.E.C. HEC-1 Hydrograph Package; Water Resources Support Center: Davis, CA, USA, 1998.

16. Huber, W.C.; Dickinson, R.E. Storm Water Management Model. User's Manual; U.S. Environmental Protection Agency: Athens, GA, USA, 1988

17. Chen, A.S.; Hsu, M.H.; Chen, T.S.; Chang, T.J. An integrated inundation model for highly developed urban areas. Water Sci. Technol. 2005, 51, 221-229.

(C) 2014 by the authors; licensee MDPI, Basel, Switzerland. This article is an open access article distributed under the terms and conditions of the Creative Commons Attribution license (http://creativecommons.org/licenses/by/3.0/). 